Бондаренко М. I., науковий співробітник Національного історико-етнографічного заповідника "Переяслав"

Дунайна I. Г., молодший науковий співробітник Національного історико-етнографбічного заповідника «Переяслав»

\title{
ПЕРЕЯСЛАВСЬКИЙ ПЕРІОД ЖИТТЯ ДВОРЯНСЬКОЇ РОДИНИ ГОРЧАКОВИХ
}

Анотація. Історія кожного українського містечка сповнена численними іменами людей, які внесли непересічний вклад у розвиток його культури. До такої когорти належали ціла низка меценатів, які своєю доброчинністю прагнули збагатити духовну культуру населення краю: будували храми, відкривали школи, опікувалися навчальними закладами та лікарнями для малозабезпечених. До таких доброчинців належала і родина князів Горчакових. Успішна підприємницька та комерційна діяльність зі значними прибутками дозволила династії Горчакових займатися благодійництвом, зокрема спонсорством, меценатством і колекціонуванням творів мистецтва.

Мета статті - огляд переяславського періоду життя князів Горчакових, який починається з 1870 року. Саме цього року вони стають володарями ташанських угідь. У ці часи найсвітліший князь К. Горчаков планує розпочати розбудову маєтку та будівництво нового палацу. Пишно вбраний i художньо оформлений комплекс був одним із найбагатших та найкрасивіших маєтків свого часу. На жаль, епоха садибної культури закінчилась із перемогою Жовтневого перевороту 1917 року. Сам палац був розграбований та знищений місцевими жителями. Про його велич і красу пам'ятає лише парк «Ташань», пам'ятка садово-паркового мистецтва XVIII століття, серед якого він колись був розташований. Свого часу родина Горчакових успішно займалася не лише підприємницькою, але й громадською діяльністю та добродійництвом. На їхні кошти були збудовані: початкова школа для діток працівників економії, церковнопарафіяльна школа при Костянтинівській церкві, лікарня на шість місць для хворих із приміщеннями для проживання медичного персоналу. Крім того, родина входила до опікунської ради переяславської жіночої гімназії. За часів володіння ташанським маєтком Горчакови багато зробили як для розбудови та впорядкування своїх переяславських володінь, так і для селян навколишніх поселень.

Ключові слова: родина Горчакових, доброчинці, меценати, маєток, палац, парк, Ташань.

Постановка проблеми. Історія повсякденності є складовою частиною соціальної історії, яка передбачає вивчення життя конкретних людей, представників різних соціальних груп і станів. Кожне українське містечко славиться численними іменами людей, які внесли свій вклад у розвиток його культури. До такої когорти можна віднести цілу низку меценатів, доброчинців, які прагнули збагатити духовну культуру населення краю: будували храми, відкривали школи й опікувалися навчальними закладами. Дослідження обраної проблеми диктується необхідністю сучасного переосмислення багатьох суттєвих аспектів, пов'язаних з особистостями, аналізом діяльності та здобутків, можливістю зрозуміти події обраного історичного періоду.

Аналіз останніх досліджень і публікацій базується на працях наукового та публіцистичного характеру, маловідомих науковому загалу сторінок у краєзнавчій історії, а саме роботах Л. Набок, Д. Розовик, О. Розовик, В. Краснюк, М. Шевченко, О. Жам, Н. Ткаченко, І. Дунайної, Т. Музики. У даних дослідження розглядаються окремі сторінки життя дворянської родини Горчакових на Переяславщині. На особливу увагу заслуговує нарис переяславського краєзнавця Ю. Коржова «Ташань. Історія та родовідна книга села Переяславського краю», який натепер є одним із перших вагомих досліджень історії села Ташань.

Дослідження діяльності визначних постатей минулого не втрачають своєї актуальності і на сучасному етапі розвитку суспільства. Спробу вирішення однієї з таких проблем зроблено у пропонованій статті, метою якої є аналітичний огляд переяславського періоду життя князів Горчакових.

Виклад основного матеріалу дослідження. У минулі часи добродійність та меценатство було справою звичайною та вельми поважною. Саме завдяки такій справі з історією Переяславщини було пов'язано низку відомих доброчинців, які відзначились своїм вагомим внеском у культурну й духовну спадщину краю. Серед них відома родина князів Горчакових. Вони належали до стародавнього російського дворянського роду, що походив від ярославських князів Рюриковичів. Родина проживала в Санкт-Петербурзі володіла значними статками. Переяславський період історії родини Горчакових починається з 1870 р., коли вони стають володарями ташанських угідь. Справами ташанської економії займався князь Костянтин Олександрович Горчаков, син канцлера Олександра Михайловича і Марії Михайлівни Стурдза, дочки молдавського князя, турецького підданого. Мав чин шталмейстера імператорського двору, прославився як надзвичайно талановитий підприємець, який міг заробити статок у 75 мільйонів рублів. Саме в ці часи найсвітліший князь планує розпочати розбудову маєтку та будівництво нового палацу.

Романтичний палац князів Горчакових у старовинному маєтку був окрасою не тільки Переяславського повіту, а й усієї Полтавської губернії. Він був зведений наприкінці XIX - на початку XX ст. за проєктом видатного архітектора Олександра-Едуарда Юлійовича Ягна. У цей час будівельне мистецтво 
розвивалось за принципами класики й еклектики (новітньої стилізації історичних взірців - готики, ренесансу, бароко тощо). Пишно вбраний і художньо оформлений комплекс був одним is найбагатших та найкрасивіших маєтків свого часу. На жаль, епоха садибної культури закінчилась із перемогою Жовтневого перевороту 1917 р. Із маєтку частково були вивезені культурні цінності власниками, а на решту чекала сумна участь. Сам палац був розграбований та знищений місцевими жителями. Він мав би стати перлиною історико-культурної спадщини, але йому, на жаль, не судилося. Про його велич та красу пам'ятає лише парк «Ташань», пам'ятка садово-паркового мистецтва XVIII ст., серед якого він був розташований.

Свого часу парк «Ташань» займав понад 150 га. У 1775 p. граф П. Рум'янцев-Задунайський, який на той час володів Ташанню, закладає парк, використовує водночас природну місцевість 3 існуючими там ярами та балками. Ще до його створення в низинах обраної під парк території росло багато різних дерев і кущів. Особливо серед них виділялися дуби віком понад 700-900 років, висаджені ташанцями ще до часів Київської Русі. Цей рукотворний лісовий масив жителі села використовували влітку як прихисток від спеки для корів, овець і табунів коней. Існуючі лісові насадження та рельєф місцевості надавали новостворюваному парку особливої природної краси, а численні насадження дерев та різноманітні кущі створювали в літній жаркий період приємну прохолоду і зволожений для місцевості мікроклімат.

За часів управління князем М. Голіциним ташанськими землями паркова зона була розширена та доповнена новими насадженнями. Упродовж всього XIX ст. парк територіально постійно збільшувався, зростав у ньому й масив висаджених дерев і кущів різних порід.

У часи Горчакових парк зазнав значних позитивних змін. Він був розширений, окультурений та доповнений рядом хвойних та листяних порід дерев, кущів які були завезені з різних куточків світу. У парку були висаджені такі екзотичні породи дерев, як дуб пірамідальний, клен канадський сріблястий, гледичія, сосна Веймутова, сосна кримська, бархат амурський, ялина срібляста, каштан звичайний, каштан їстівний, туя звичайна, береза повисла, граб, клен гостролистий, берест, вільха, дуб черешчатий, акація біла, акація жовта, бересклет, сосна звичайна, ялина звичайна. Протягом декількох років було створено три озера зі штучними острівцями та місточками. У них розводили рідкісні породи риб. Окремі галявини 3 «альпійськими» квітниками плавно переходили у природний ліс. Безперечним серцем маєтку був палац. Його було видно здалеку, завдяки величним формам та вдалому розташуванню на пагорбі. Замок було побудовано з рисами середньовічного палацу. На центральному фасаді - дві високі вежі, парадний вхід і домова церква. Збоку ще дві напівкруглі вежі менших розмірів. Вежа над головним входом була головною; її витягнутий догори купол зі шпилем нагадував дзвіницю, власне для цього вона і слугувала. Прикрасами слугували характерні для класичного стилю ступінчасті карнизи з подвійними опоясаннями. Цю домінанту замку врівноважувало ліве крило, верхівка якого була струнка та ступінчатої форми, а гранований бік вівтаря із шатровим верхом завершував композицію. Дві ці вежі об'єднувались житловими приміщеннями: розділялися подвійним широким опасанням, а широкі напівкруглі вікна займали майже весь простір. Над центральним вікном було трикутне шатрове закінчення з великими золотими кулями на верхівках. Відстань між баштами у просторі з'єднував видовжений до гори дах із численними слуховими віконцями 3 гострими куполами та стрімкі північні димоходи. Завершували цілісність композиції всієї будівлі дві напівкруглі башти службових приміщень, верх яких закінчували круглі шпильові куполи. За розповідями очевидців, у палаці було 96 кімнат. Поруч стояло приміщення театру - кам'яне, із червоної цегли, воно мало, як палац, великі напівкруглі вікна та невелику башту із шатровим куполом, i за стилем вдало поєднувалось із палацом. У цьому ж павільйоні був улаштований невеличкий природно-етнографічний музей. Різноманітна діяльність власника маєтку, пов’язана 3 великим господарством, мала вплив на будівництво цілої низки споруд на території господарчої зони припалацевої частини садиби. Окрім замку, була ще велика кількість службових приміщень: хлібні комори, стайні, пральна, дерев'яний двоповерховий флігель. При маєтку проживав головний управитель князя Горчакова в Ташані Петро Олексійович Шимкович зі своєю родиною. У цей час князь будує декілька нових приміщень: оранжерею, теплицю, звіринець та зимовий сад. На західному боці від палацу був улаштований пташник, де утримували фазанів, павичів та інших птахів [1, с. 63].

Горчакови залишили помітний слід у господарському та суспільному розвитку Переяславщини. Господар маєтку, найсвітліший князь Костянтин Олександрович Горчаков, багато зробив як для розбудови та впорядкування Ташані, так і для навколишніх сіл. Володів більше 14 тис. десятин землі, лісовими угіддями тільки в самому Переяславському повіті. У 1885 р. заснував біля села Пологи-Яненки цегельний завод на дві опалювальні печі, де працювало 15 чоловіків і 1 жінка. 31904 р. на заводі вироблялось 250 тисяч цеглин, що використовувались тільки для потреб ташанської економії. Цегла була дуже високої якості. Селяни Переяславщини по цей день згадують про неї гарними словами та пам'ятають клеймо з ініціалами «К. Г.», яке наносилось на кожну цеглину. Успішна підприємницька та комерційна діяльність зі значними прибутками дозволяла династії Горчакових займатися благодійництвом, спонсорством, меценатством та колекціонуванням творів мистецтва. Так, у 1895 р. в селі Ташань на власні кошти князь будує початкову школу для діток працівників економії. У 1901 р. лікарню на шість місць для хворих, із приміщеннями для проживання медичного персоналу [1, с. 60-61]. У 1904 р. в урочищі Озерище Хоцьківської волості Переяславського повіту була побудована церковнопарафіяльна школа при Костянтинівській церкві [2, с. 63].

Костянтин Олександрович мав двох доньок та трьох синів. У літній період родина приїздила до свого ташанського маєтку. У спогадах жителів Ташані Костянтин Горчаков залишився доброю, порядною людиною, до нього будь-хто міг звернутись по допомогу та пораду. Любив він і сільських дітей. Часто, коли князь проїжджав у своїх справах через село, його карету обступала сільська дітвора, якій роздавались цукерки та солодощі. У Ташані по цей день передається розповідь про те, як у селі проживав молодий хлопець, який за один раз міг з’їсти ціле теля. I ось, коли до князя приїхали поважні гості, він запросив до себе на обід цього селянина. Господарю дуже хотілось похизуватись перед гостями таким справним хлопцем. Теля приготували 3 різноманітними стравами, накрили стіл на широкій галявині перед замком. Молодий хлопець, з’ївши все, що було 
приготовлено на столі, із подивом запитав: «А де ж те теля, що я повинен з'їсти?» [3]. Як сам князь, так і його діти займалися меценацтвом та добродійництвом. Родина вкладала гроші не тільки в розкішне життя для себе, а й в освіту сільських та міських українських дітей. Молодша дочка князя, Олена Костянтинівна, виконувала обов'язки «попечительниці» переяславської жіночої гімназії в 1904-1907 pр. Син, Олександр Костянтинович Горчаков, найсвітліший князь, був предводителем дворянства Переяславського повіту в 1901-1913 рр., головою Товариства допомоги нужденним та Товариства в допомозі бідним учням у м. Переяславі, а також головою опікунської ради жіночої гімназії (1902-1904рр.). У 1907 р. князь подарував переяславській хлоп'ячій гімназії для належного облаштування природничого кабінету частину таксідермістікофілічної збірки, зокрема черепи африканських тварин, чучела птахів, ящірок. За кошти князя в гімназії в 1909-1915 рр. в кожному класі навчалося по два учні. У своєму ташанському маєтку мав природничо-етнографічну колекцію, яку зберігав в окремому будиночку, дозволяв сільським школярикам іiї періодично оглядати. Молодший син, Михайло Костянтинович, у 1913-1916 рр. був почесним наглядачем переяславського чоловічого училища.

Як господар маєтку, так і його старший син Олександр були завзятими мисливцями та рибалками. У свій час, незважаючи на те, що Олександр $з$ дитинства був близоруким, навіть двічі був на полюванні в Африці. Родина мала дуже гарну колекцію мисливської зброї. У замковій псарні, яка розташовувалась біля другого озера, доглядали хортів і гончих псів для полювання на дичину. За особистим проєктом у 1909 р. Олександр Костянтинович в урочищі Біле Озеро Хоцьківської волості Переяславського повіту будує мисливський будинок у мальовничій місцевості, неподалік від Дніпра. Двоповерховий будинок на вісім кімнат із мезоніном, двома верандами, двома коридорами повністю був збудований із дерева місцевими майстрами. Освітлювався 15 вікнами, у холодну пору року отоплювався чотирма грубами. Дерев'яні східці, які були розміщені недалеко від центрального входу, з коридору вели до мезоніну, де розмістилась одна невеличка кімната поряд із горищем.

Мисливська дача виконувала функцію місця для кількаденного перебування господаря та гостей під час полювання. Вона не мала жодних парадних функцій і не мала якого-небудь значного господарства. У комплексі дачі були побудовані конюшні, псарні, декілька інших господарських споруд які оживали під час полювання. У приміщенні для челяді жили конюхи, лісники, кухарки, садівники. Доля мисливського будинку була набагато кращою від ташанського палацу. Після 1917 р. сама будівля використовувалась у різних цілях. До 1968 р. у приміщенні знаходився відділок Білоозерського лісництва. У будинку проживала сім'я лісника, об'іждчики лісових угідь, які, крім того, доглядали за будинком, службовими приміщеннями. Інформатор Любов Яківна Коноваленко пригадує, що в цьому будинку жила з батьками до 1959 р. (на той час їй було 6 років). Її батько працював бухгалтером у лісництві. Жили вони на першому поверсі в кімнаті, де раніше була їдальня. У будинку, на першому та другому поверсі, проживало 3-4 сім’ї працівників лісового господарства. Відділення Білоозерського лісництва також було розташоване в цьому приміщенні, у кімнаті великої вітальні. Центральний вхід був там, де й зараз. Будинок Горчакова знаходився в низовині, постійно відчувалась вологість. За 200 м від приміщення було озеро [4]. У 1968-1969рр. мисливський будинок був перевезений та встановлений на території Музею народної архітектури та побуту Середньої Наддніпрянщини Національного історико-етнографічного заповідника «Переяслав». У будинку був відтворений затишний інтер'єр із мінімумом декоративних прикрас, витриманий у так званому «мисливському стилі». Навколо самої будівлі була створена паркова зона 3 фонтаном, альтанкою, березовою алею та ротондою. Серед унікальних експонатів - дві фаянсові чашечки (К-81, НДФ-809), які належали родині Горчакових[5]. Виготовлені вони були на заводі М. Кузнєцова на замовлення князя К. Горчакова на честь одруження сина Олександра Горчакова та Дарії Бібікової, яке відбулося навесні 1904 р. Чашки мають циліндричну форму, на бочках зображений зовнішній вигляд палацу князя Горчакова в с. Ташань Переяславського повіту Полтавської губернії, вензель князя та дата шлюбу «7.04.1904». Чашки виготовлені 3 тонкого фаянсу. Передані вони були до Переяслава-Хмельницького історичного музею в 1962 р. жителькою с. Ташань Одаркою Самутіною. Дісталися вони їй від матері, Марії Лабузної, яка працювала в маєтку Горчакова. Відомостей про те, як дані предмети потрапили до цієї жінки, у записах немає.

Після смерті Олександра Костянтиновича, який помер від важкого поранення в 1916 р., родина назавжди покинула свій маєток і більше ніколи не приїжджала. У 1919 та 1920 рр., рятуючись від більшовицького терору, Горчаковивиїхали за кордон. На території сучасного парку збереглася могила середнього сина Бориса Костянтиновича Горчакова. Він помер у віці двадцяти одного року. За спогадами жителя села Ташань Володимира Миколайовича Аношкіна, його бабуся, Василиса Логвіновна, була головною покоївкою в ташанському маєтку. Бабуся розповідала, як восени молодий князь недалеко від маєтку ловив рибу. Човен перевернувся і Борис опинився в холодній воді. Застуда спричинила туберкульоз, який лікували італійські лікарі в місті Гордона-Рів'єра. Ослаблений організм не зміг побороти хворобу. Помер Борис у 1900 р. Його поховали в Ташанському парку між чотирма кленами, недалеко від фамільного палацу [6]. У часи так званого революційного вандалізму, розграбувавши маєток, місцеві жителі добрались і до поховання. Василиса Логвіновна розповідала, як прибіг до неї один із жителів Ташані та сповістив про знущання над могилою покійного. Прийшовши до поховання, вона побачила жахливу картину - могила була розрита, труна 3 покійником розкидана, навіть одяг, у якому був похований Борис, - знято. Частину камфори, якою був обкладений покійник для бальзамування, забрано, а частину розкидано. Добре, що знайшлися в селі чоловіки, які на прохання колишньої покоївки зробили нову труну та перепоховання [6]. Натепере старий масивний дерев'яний хрест, що був поставлений біля могили, місцеві ентузіасти замінили на металевий, зробили навколо невеличку огорожу.

Висновки. Слава палацу щезла у вогні революції. Після від’їду Горчакових садиба зазнала погрому та підпалу. Були знищені та розграбовані твори мистецтва, знищений інтер'єр, згоріли дерев'яні будівлі. Не один селянин із палацової цегли побудував собі будинок. На жаль, сьогодні від парку та самого палацу залишились чагарники та старі світлини. Парк волає про порятунок! Заросли ставки, замулились джерела, поламались рідкісні зелені насадження, які колись були завезені з європейських і північноамериканських країн. Місце, де колись стояв сам палац, перетворилося на непрохідні хащі. Парк, який є пам'яткою садово-паркового мистецтва загальнодержавного значення, потребує термінового впорядкування та постійного догляду. 


\section{Jimepamypa:}

1. Коржов Ю. Ташань. Історія та родовідна книга села Переяславського краю: у 2-х т. Чернігів : Вид. Лозовий В.М., 2017. Т. 1. 280 с.

2. Набок Л. Головні об'єкти уваги переяславських благодійників у XIX - поч. XX ст. Меценатство та його роль в суспільно-економічному і культурному житті України : матеріали Наукової конференції, Качанівка, 29-30 липня 2010 р. Качанівка, 2010. С. 60-69.

3. Польові матеріали авторів. Записано 15.10 .2019 р. від Аношкіна В.М., 1939 р. н., мешканця с. Ташань Переяслав-Хмельницького району Київської обл.

4. Польові матеріали авторів. Записано 04.07.2015 р. від Коноваленко Л.Я., 1953 р. н., мешканки м. Ірпінь Київської обл.

5. Фонди Національного історико-етнографічного заповідника «Переяслав». Інвентарні книги № 1 «Кераміка» (К), Інвентарна книга № 1 науково-допоміжного фонду (НДФ).

6. Польові матеріали авторів. Записано 15.10.2019 р. від Аношкіної T.М., 1941 р. н., мешканки с. Ташань Переяслав-Хмельницького району Київської обл.

Bondarenko M., Dunaina I. Pereiaslav period of life of the Gorchakov family

Summary. The history of each Ukrainian town or village is rich indifferent names of people who have made an important contribution to the development of its culture. This community included a lot of philanthropists who tried to enrich the spiritual culture of the population of the region: building temples, opening schools, educational institutions and hospitals for the poor. The family of princes Gorchakov was such benefactors. Successful entrepreneurial and commercial activities with significant profits have allowed them to engage in charity, in particular sponsorship, patronage and art collecting.

The aim of this article is to show the life of princes Gorchakov in Pereiaslav, which begins in 1870. Since this year they have become owners of Tashan lands. Prince K.O. Gorchakov planned to build the estate and a new palace. The luxuriously decorated and artistically designed complex was one of the richest and most beautiful estates. Unfortunately, the epoch of estate culture ended with the victory of the October Revolution in 1917. The palace was completely plundered and destroyed by the locals. Only the Tashan Park, a monument of the landscape art of the 18th century, testifies to its beauty and grandeur. The Gorchakov family was successfully engaged not only in entrepreneurship, but also in social activity and charity. At their expense they were built: elementary school for children of their workers, parish school at the Konstiantynivska church, and hospital for six places for patients and with accommodation for medical staff. In addition, the family was a member of the board of trustees of the Pereiaslav women's gymnasium. In times of ownership of the Tashan estate, they built and arranged their Pereiaslav estates and the surrounding settlements.

Key words: Gorchakov family, benefactors, philanthropists, estate, palace, park, Tashan. 